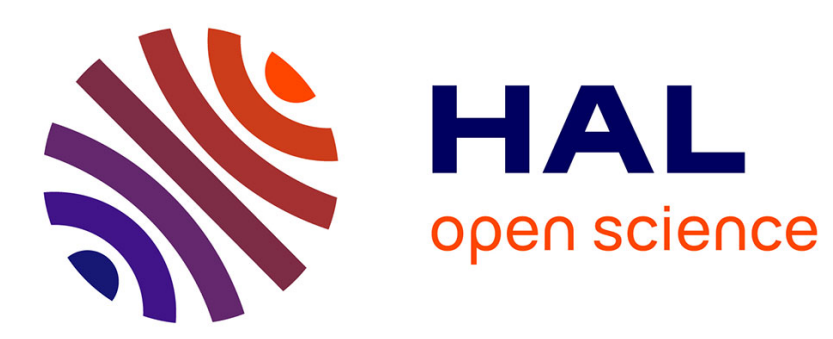

\title{
The Transaqua Project: Narrative and Constructivist Analysis
}

Joseph Mimbale

\section{To cite this version:}

Joseph Mimbale. The Transaqua Project: Narrative and Constructivist Analysis. Academia Letters, 2021, 10.20935/al3500 . hal-03494298

\section{HAL Id: hal-03494298 \\ https://hal.science/hal-03494298}

Submitted on 19 Dec 2021

HAL is a multi-disciplinary open access archive for the deposit and dissemination of scientific research documents, whether they are published or not. The documents may come from teaching and research institutions in France or abroad, or from public or private research centers.
L'archive ouverte pluridisciplinaire HAL, est destinée au dépôt et à la diffusion de documents scientifiques de niveau recherche, publiés ou non, émanant des établissements d'enseignement et de recherche français ou étrangers, des laboratoires publics ou privés. 


\title{
ACADEMIA $\mid$ Letters
}

\section{The Transaqua Project: Narrative and Constructivist Analysis}

\author{
Joseph Mimbale, Université de Kinshasa
}

This article sets out to explain why the narrative of the Transaqua project should be understood prior to any analysis and why it is appropriate to think this initiative in terms of the constructivist approach to international relations. For several decades, the issue of the rescue of Lake Chad by the waters of the Congo has dominated both the African regional universe and the international chronicle. It is also the backdrop for several scientific publications covering various fields. In International Relations, the issue has been explored more under the anchor of classical theoretical approaches. Very little research has attempted to address the initiative according to the analytical logics of critical theoretical approaches such as constructivism which is powerful for its multi-causal explanation of social phenomena, its emphasis on social context, intersubjective arrangements, the social construction of national interest and the constitutive nature of initiatives and actors.

When we try to comb through the existing literature on the issue of mega water transfer projects such as Transaqua, we cannot help but notice that much of the literature on the politics of large-scale water infrastructure is centred on classical theoretical schemes enshrining the centrality of the state, the West, urban development and even urban modernism [1]-[6]. Too often, case studies have focused on river bodies, transboundary basins, shared basins, shared water resources...in developing countries [7]. These approaches focus on issues of territorialisation of governmental power, legitimisation of state power, nationalisation, sovereignty and other forms of political competence [8]-[10].

With the inter-basin transfer to Lake Chad, social scientists have focused more on 'hydropolitical' analysis, such as Magrin's [11] political-ecological research on Lake Chad. Of course, Magrin sees the inter-basin transfer of water to restore the mythical disappearance of the lake as being motivated by various political interests. In contrast, from a hydro-security

Academia Letters, September 2021

(C2021 by the author - Open Access - Distributed under CC BY 4.0

Corresponding Author: Joseph Mimbale, joseph_mimbale@yahoo.com

Citation: Mimbale, J. (2021). The Transaqua Project: Narrative and Constructivist Analysis. Academia Letters, Article 3500. https://doi.org/10.20935/AL3500. 
and regional integration perspective, Ifabiyi [12] believes that an inter-basin water transfer to Lake Chad would offer potential benefits in addressing the terrorist threat in the region, and would consequently enhance regional cooperation and development of landlocked Central African countries. Both papers mentioned the two main inter-basin water transfer schemes proposed to replenish Lake Chad (Oubangui and Transaqua), although neither offered full multi-causal explanations of either project.

However, a constructivist analysis of water transfer mega-projects has the advantage of offering a perspective on the nature of actors (state, group, communities, individuals) and their relationships to wider structural environments. Its philosophy is one of mutual constitution in which no unit of analysis - actor/structure - is reduced to the other. The interest of actors emerges 'from' and is endogenous 'to' the interaction with the structure at the first level and other actors at the second level, with neither having analytical primacy over the other [13]. This being said, in order to consider the Transaqua Project and the future of the basins concerned, it is important to take into account 5 levels of analysis:

- Transaqua's narrative framework: which helps to understand Transaqua's discursive logics. The narrative is, in fact, centred on the level of the actantial structure [14] - which is an essential discursive framework from which the narrative structure is constructed, and around which it is possible to derive the semantic-logical relations concerning "doing" - a kind of logic of action that must be deciphered in order to better apprehend the spirit or dimension of the discursive scope. From this perspective, the narrative of the Transaqua project is structure around three (3) fundamental aspects: a major transport infrastructure, the production of electrical energy and agroindustrial development. Indeed, in order to eradicate the poverty afflicting most of the African population, Transaqua opts for the large-scale development of communication infrastructures. An infrastructure development that should lead to the improvement of services and the production of sufficient quality and quantity of electrical energy for industry and households... which will enable the riparian states to significantly improve the standard of living of their populations. Since the narrative is a component of the internal circuit of the discourse that organises the "it" from the point of view of actions, that is, everything that concerns the description of facts, which we should call "the pragmatics of actions", it will allow us not only to describe the Transaqua project, but also, and above all, to elucidate the semantic-logical relations in the organisation of the actions (actancial schema) around the Transaqua initiative.

- The contextualisation of social phenomena: without the contextualisation of the Transaqua initiative, we will not be able to understand the position or the engagement of the dif- 
ferent actors.

- Intersubjective arrangements: because reality is not given once and for all; it is intersubjective, i.e. it depends on the meaning given to it by the actors. Thus, more than power relations, it is perceptions that guide the behaviour of states. This is why the overlapping dynamics of events around Transaqua cannot be understood without first taking into account the intersubjective nature of discourses, relationships, images and perceptions. Hence the interest in exploring this analytical grid in order to fully understand the way in which the contexts in which Lake Chad and the waters of the Congo are situated are developing, their consequences on the attitude of the actors, and on the possibility of concretising the Transaqua initiative.

- The social construction of the national interest: indeed, Transaqua appears today as a project that looks like an "international conspiracy". Conspiracy because the project is at a very advanced stage of discussions between several states, business circles and international experts, discussions in which the Congolese population and state have not been sufficiently involved. Transaqua's narrative, which we have noted in the first point, tells of the benefits that the riparian states would gain from the project. Gains in terms of interests and the power to develop. However, state interests cannot be simply deduced from the strategic distribution of economic or even material power [15]. There is also a social power component that needs to be considered in the approval of large-scale initiatives.

- The constitutive nature of initiatives and actors: this will allow us to analyse the set of actors, their role...These actors can be States, epistemic communities, social movements, NGO networks, or even societies themselves.

The intersubjective perception of the Transaqua initiative by the actors has contributed greatly to bringing them together through meetings, summits, forums and high-level conferences. It should be remembered that we started from a proposal in the 1980s that did not evolve too much - due to environmental considerations, regional geopolitics, its unilateralism and, above all, its cost, which was out of the reach of the actors and which, presumably, aroused considerable interest at the time without obtaining the favourable opinion of the States of two basins - to a much more constructive proposal which, due to the support of a number of actors, offers greater possibilities for its materialisation. The approval of the Transaqua inter-basin water transfer project at the International Conference for the Safeguarding of Lake Chad - held in Abuja from 26 to 28 February 2018 - was an important step in this process. Of course, the Transaqua project has had many uncertain moments. Uncertainties about the 
actors, about funding and about geopolitical considerations. However, intersubjectivity ensures that the actors co-construct and rearrange their positions and interests. And from a constructivist point of view, the fact that the LCBC states accepted the DRC's demands by ordering a first feasibility study of the Transaqua initiative is proof of co-constitution, social co-construction and, above all, a consideration of regional socio-political susceptibilities. Even if for sovereignist reasons and taking into account the very complex political context in the DRC, it should be stressed that anything can happen depending on contexts, intersubjective arrangements, interests, actors and/or structures.

We can therefore argue, finally, that the ideas surrounding the Inter-basin Water Transfer venture (in particular the Transaqua project) represent a window of opportunity for several actors to pursue their broader socio-economic and political agendas in the Lake Chad and Congo basins. Perhaps this is why they are motivated to promote Transaqua in line with economic and socio-political agendas. It should also be noted that some potentially influential actors, such as UNESCO, the World Bank and CICOS, which are expected to play a key role in the Inter-basin Water Transfer processes in the near future, have not finalised their position on the issue. This leads us to understand that, indeed, norms and institutions are not born in a vacuum. The question is not only the presupposition that if reality is a social construct...it is easily changed if the actors want to. Thus, norms, proposals or initiatives must constantly be formulated, defended and legitimised by the actors. And it is up to them to justify such and such initiatives, proposals or actions - to discuss them, to reconcile divergent points of view and to defend them in the public space. Hence the interest of the approach of a co-construction of initiatives and actors in this Transaqua process.

\section{References}

[1] F. Ghassemi and I. White, Inter-Basin Water Transfer: Case Studies from Australia, United States, Canada, China and India (International Hydrology Series), Cambridge. Cambridge, 2007.

[2] C. Liu and H. Zheng, "South-to-north Water Transfer Schemes for China," Int. J. Water Resour. Dev., vol. 18, no. 3, pp. 453-471, Sep. 2002, doi: 10.1080/0790062022000006934.

[3] S. Moore, "China's domestic hydropolitics: an assessment and implications for international transboundary dynamics," Int. J. Water Resour. Dev., vol. 34, no. 5, pp. 732-746, Sep. 2018, doi: 10.1080/07900627.2017.1313157.

[4] J. D. Rinaudo and B. Barraqué, "Inter-Basin Transfers as a Supply Option: The End of 
an Era?," Glob. Issues Water Policy, vol. 15, no. July 2016, pp. 175-200, 2015, doi: 10.1007/978-94-017-9801-3_8.

[5] M. Webber, B. Crow-Miller, and S. Rogers, "The South-North Water Transfer Project: remaking the geography of China," Reg. Stud., vol. 51, no. 3, pp. 370-382, 2017, doi: 10.1080/00343404.2016.1265647.

[6] L. Zhang, S. Li, H. A. Loáiciga, Y. Zhuang, and Y. Du, "Opportunities and challenges of interbasin water transfers: a literature review with bibliometric analysis," Scientometrics, vol. 105, no. 1, pp. 279-294, Oct. 2015, doi: 10.1007/s11192-015-1656-9.

[7] N. Mirumachi, "The politics of water transfer between South Africa and lesotho: Bilateral cooperation in the lesotho highlands water project," Water Int., vol. 32, no. 4, pp. 558570, 2007, doi: 10.1080/02508060.2007.9709688.

[8] K. Bakker, Privatizing Water: Governance Failure and the World's Urban Water Crisis, Cornell Un. London, 2010.

[9] B. Crow-Miller, "Discourses of deflection: The politics of framing China's South-North water transfer project," Water Altern., vol. 8, no. 2, pp. 173-192, 2015.

[10] J. Obertreis, T. Moss, P. P. Mollinga, and C. Bichsel, "Water, infrastructure and political rule: Introduction to the special issue," Water Altern., vol. 9, no. 2, pp. 168-181, 2016.

[11] G. Magrin, “The disappearance of Lake Chad: History of a myth,” J. Polit. Ecol., vol. 23, no. 1, pp. 204-222, 2016, doi: 10.2458/v23i1.20191.

[12] I. Ifabiyi, "Recharging the Lake Chad: the Hydropolitics of National Security and Regional Integration in Africa," African Res. Rev., vol. 7, no. 3, pp. 196-216, 2013, doi: 10.4314/afrrev.v7i3.15.

[13] T. Braspenning, "Constructivisme et reflexivisme en théorie des relations internationales," Annu. Français Relations Int., vol. 3, no. 1, pp. 314-329, 2002, [Online]. Available: https://www.afri-ct.org/wp-content/uploads/2006/03/braspenning2002.pdf.

[14] G. Imbert, "Stratégies discursives et non-dit dans les discours de la presse - A propos de 'El País,"' Melanges Casa Velazquez, vol. 18, no. 1, pp. 361-379, 1982, doi: 10.3406/casa.1982.2372.

[15] A. Klotz and C. Lynch, "Le constructivisme dans la théorie des relations internationales," Crit. Int., vol. $\mathrm{n}^{\circ} 2$, no. 1, pp. 51-62, 1999, doi: 10.3917/crii.p1999.2n1.0051.

Academia Letters, September $2021 \quad$ C2021 by the author — Open Access — Distributed under CC BY 4.0

Corresponding Author: Joseph Mimbale, joseph_mimbale@yahoo.com

Citation: Mimbale, J. (2021). The Transaqua Project: Narrative and Constructivist Analysis. Academia Letters, Article 3500. https://doi.org/10.20935/AL3500. 